\title{
Implementasi Metode Profile Matching untuk Menentukan Penerima Beasiswa Bidikmisi
}

\author{
Implementation of Profile Matching Method \\ to Determine Scholarship Recipients Bidikmisi
}

\author{
Elvis Pawan*1, Wahyu Wijaya Widianto ${ }^{2}$, Patmawati Hasan ${ }^{3}$ \\ ${ }^{1.3}$ STIMIK Sepuluh Nopember Jayapura; Ardipura II No 22B \\ ${ }^{2}$ Politeknik Indonusa Surakarta \\ e-mail: *1elvispawan09@gmail.com, 2wahyuwijaya@poltekindonusa.ac.id, \\ patmawatihasan@gmail.com
}

\begin{abstract}
Abstrak
Proses seleksi beasiswa bidikmisi secara manual, mulai dari pengajuan formulir sampai penetuan mahasiswa penerima beasiswa semua dikerjakan secara manual sehingga pada proses pemberian bantuan pendidikan kepada mahasiswa terkdang tidak objektif karena banyaknya minat mahasiswa dari tahun ke tahun yang mengajukan permohonan beasiswa bidikmisi, keterbatasan waktu yang dimiliki kerap menyulitkan tim dalam menentukan mahasiswa yang tepat untuk menerima beasiswa. Diperlukan sebuah SPK yang dapat mempermudah pekerjaan tim dan dapat membantu memperoleh penerima beasiswa secara objektif. Sistem pendukung keputusan yang diusulkan dengan menggunakan metode profile matching dengan mempertimbangkan beberapa kriteria seperti potensi akademik, ekonomi keluarga, jumlah tanggungan orang tua, kelengkapan berkas, dan transportasi ke kampus. Penelitian ini menghasilkan sebuah sistem pendukung keputusan dan berdasarkan data yang dimasukkan pada sistem jika nilai core factor (CF) sebesar 65\% dan secondary factor sebesar 35\%, maka dari data yang ada terdapat lima orang yang berhak memperoleh beasiswa menurut rangking satu sampai lima yaitu M03, M09, M06, M07, dan M08. Dari pengujian yang dilakukan sebanyak 84\% responden menjawab positif terhadap hasil sistem pendukung keputusan karena dapat membantu mereka untuk menjalakan tugas dan tanggungjawab sebagai tim seleksi.
\end{abstract}

Kata kunci-Profile_Matching; Beasiswa; SPK; Bidikmisi

\begin{abstract}
The manual selection process for Bidikmisi scholarships, starting from submitting forms to determining scholarship recipients, is all done manually so that the process of providing educational assistance to students is sometimes not objective because of the high interest of students who apply for Bidikmisi scholarships from year to year. makes it difficult for the team to determine the right student to receive the scholarship. A DSS is needed that can facilitate the team and can help objectively obtain scholarship recipients. The proposed decision support system uses the profile matching method by considering several criteria such as academic potential, family economy, number of dependents of parents, completeness of files, and transportation to campus. This research produces a decision support system and based on the data entered in the system if the core factor (CF) value is $65 \%$ and the secondary factor is $35 \%$, then from the existing data, five people are entitled to receive scholarships according to rank one to five, namely M03, M09, M06, M07, and M08. From the tests carried out, 84\% of respondents answered positively to the results of the decision support system because it can help them carry out their duties and responsibilities as a selection team.
\end{abstract}

Keywords_- Profile Matching; scholarships; DSS; Bidikmisi 


\section{PENDAHULUAN}

Undang-Undang Dasar 1945 menjamin hak setiap warga negara Indonesia untuk mendapatkan pendidikan secara layak tanpa memandang latar belakang [1][2]. Hal tersebut bukan tanpa alasan karena salah satu tujuan bangsa Indonesia adalah mencerdaskan kehidupan bangsa yang terkandung dalam batang tubuh UUD 1945. Karena pendidikan yang begitu penting sehingga pemerintah menyediakan fasilitas sekolah gratis bagi dan wajib belajar 12 tahun [3]. Dengan adanya fasilitas wajib belajar 12 tahun tidak secara otomatis menyelesaikan persoalan bahwa masyarakat sudah dapat memperoleh kehidupan yang layak karena saat ini standar yang diterapkan di berbagai macam perusahaan cenderung mencari lulusan sarjana [4]. Dengan dengan adanya kondisi seperti itu, banyak pemuda-pemudi yang memiliki prestasi yang baik tidak dapat memperoleh pekerjaan sesuai dengan harapan mereka, untuk mengatasi permsalahan tersebut STIMIK Sepuluh Nopember Jayapura, sebagai institusi perguruan tinggi yang membantu merealisasikan salah satu tujuan pemerintah dengan menyediakan beberapa jenis beasiswa salah satunya beasiswa bidikmisi yang dapat di manfaatkan oleh mahasiswa yang kurang mampu dan memiliki prestasi akademik yang baik.

Dengan adanya program beasiswa tersebut mengakibatkan antusias mahasiswa untuk mengajukan permohonan melalui STIMIK Sepuluh Nopember Jayapura, karena banyak mahasiswa yang mengajukan permohonan beasiswa maka memerlukan proses seleksi agar pemberian beasiswa tepat sasaran inilah salah satu alasan tersebut yang mendasari penelitian ini dilakukan. Sistem pendukung keputusan dapat mempermudah tim seleksi atau pengguna yang bertugas, salah satu metode yang baik dalam merancang sistem pendukung keputusan adalah profile matching [5] [6].

Beberapa penelitian sistem pendukung keputusan tentang penentuan beasiwa yang pernah dilakukan dengan menggunakan metode berbeda-beda diantaranya dengan menggunakan metode SAW, pada penelitian ini menyimpulkan bahwa metode SAW memiliki kecocokan antara perhitungan manual dan sistem, selajutnya penelitian tersebut memberikan saran untuk membuat sebuah penelitian terkait penentuan beasiswa dengan memanfaatkan metode selain SAW[7]. Sistem pendukung keputusan penetuan beasiswa pada universitas negeri jakarta, pada penelitian tersebut menggunakan metode SAW, perbedaan pada penelitian ini adalah metode yang digunakan dalam perancangan sistem pendukung keputusan [8].

Sedangkan metode profile matching telah beberapa kali digunakan oleh pakar untuk membuat penelitian akan tetapi pada objek maupun subjek yang berbeda-beda diantaranya profile matching digunakan untuk menentukan bibit padi terbaik, dalam penelitian ini menyimpulkan bahwa metode profile matching sangat cocok untuk merancang sebuah sistem pendukung keputusan, perbedaan pada penelitian yang dibuat adalah objek dari penetian ini berfokus pada penentuan penerima beasiswa bidikmisi [6]. Penelitian lain yang memanfaatkan metode profile matching adalah untuk menentukan beasiswa kurang mampu pada tingkat sekolah SMA dan SMK, akan tetapi pada penelitian tersebut memiliki kelemahan, yakni pengujian belum dilakukan sehingga perhitungan manual dan sistem belum diketahui kebenarannya [9] [10]. Penelitian lain yang memanfaatkan metode profile matching sistem pendukung keputusan untuk mutasi karyawan, perbedaan pada penelitian ini yaitu pada objek peneltian yaitu penentuan beasiswa bidikmisi [5].

\section{METODE PENELITIAN}

\subsection{Alur Penelitian}

Dalam melakukan penelitian ini memiliki beberapa tahapan penting, yang diilustrasikan melalui bagan pada Gambar 1, hal tersebut bertujuan agar pembaca dapat memahami langkahlangkah didalam melakukan penelitian ini. 


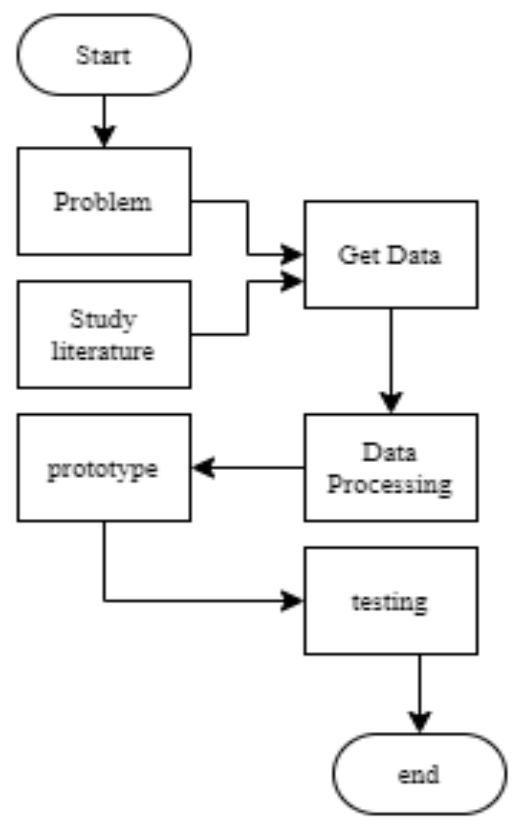

Gambar 1. Alur Penelitian

Berdasarkan Gambar 1, alur dalam penelitian ini dimulai dari Problem, merupakan masalah yang terdapat pada STIMIK Sepuluh Nopember Jayapura, yang memerlukan penyelesaian. Study literature, merupakan suatu langkah untuk memperoleh informasi terkait dengan permasalahan yang sedang dialami. Get data adalah suatu tahap untuk memperoleh data secara akurat yang bermanfaat untuk mendukung penelitian yang dibuat. Data Processing, merupakan tahap implementasi data kedalam metode profile matching. Prototype merupakan implementasi hasil pengolahan data kedalam sistem pendukung keputusan. Sedangkan testing adalah langkah terakhir untuk mendapakan akurasi hasil dari sistem pendukung keputusan.

\subsection{Metode Profile Matching}

Metode profile macthing merupakan suatu proses pembandingan antara profile yang dimiliki oleh alternatif dengan profile standar, dan perbedaan komptensinya disebut gap, hal tersebut di jelaskan pada persamaan 1 [6] [11] [12][13].

\section{Gap=profileatribut-profile target.}

Hasil akhir yang diperoleh dari profile matching adalah rangking nama-nama mahasiswa yang berhak mendapatkan beasiswa. Perangkingan didasarkan pada perhitungan kriteria yang digunakan oleh user.

\subsection{Desain Sistem}

\subsubsection{Data Flow Diagram (DFD)}

Data flow diagram merupakan representasi dari tahapan atau arus data yang terjadi pada sistem yang sedang dikembangkan atau dibuat, DFD dapat memberikan gambaran aliran data secara detail didalam sebuah sistem, sehingga dengan mudah dapat dimengerti atau dibaca [6][14][15][16]. DFD level 0 dapat dilihat pada Gambar 2 yaitu gambar Diagram Konteks. 


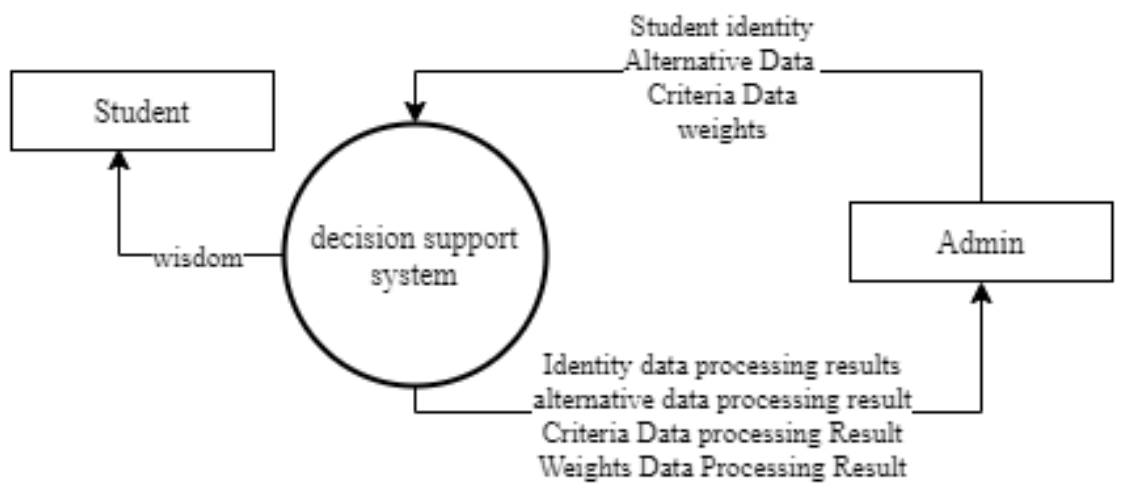

Gambar 2. Diagram Konteks

Gambar 2 menjelaskan aliran data secara umum didalam prototype yang dibuat, seorang user dapat menginput data pada DSS, seperti student idendtity, alternative data, creteria data, dan weights. Selanjutnya sistem dapat mengolah data kemudian mengembalikannya pada user atau admin dalam bentuk wisdom atau hasil. Sedangkan mahasiswa dapat memperoleh hasil keputusan dari sistem.

\subsubsection{Desain Basis Data}

Perancangan basis data merupakan sekumpalan data yang saling terintegrasi, dan tesimpan pada sebuah parangkat komputer, serata dapat dimanipulasi dengan menggunakan sebuah software [17][18][19]. Adapun rancangan basis data dapat dilihat pada Gambar 3.

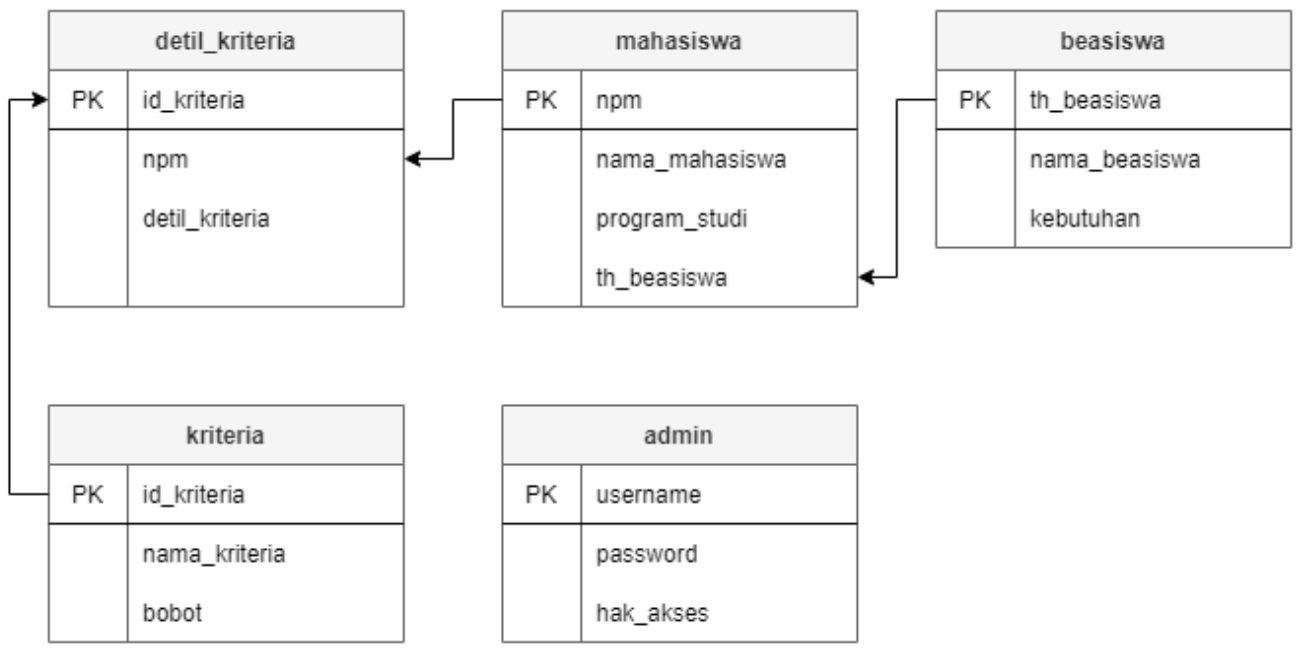

Gambar 3. Desain Basis Data

Gambar 3 menunjukkan serta menjelaskan sebuah rancangan database yang digunakan pada sistem pendukung keputusan yang dibuat. Terdapat lima tabel yaitu tabel beasiswa, mahasiswa, kriteria, dan detil_kriteria yang saling berelasi sedangkan satu tabel yang diberi nama tabel admin berdiri sendiri. Pada tabel mahasiswa berelasi ke tabel detil_kriteria dengan field npm sebagai primary key, tabel kriteria berelasi ke tabel ditil kriteria dengan field id_criteria sebagai primary key, sedangkan tabel beasiswa berelasi ke tabel mahasiswa dengan th_beasiswa sebagai primary key. 


\section{HASIL DAN PEMBAHASAN}

Mendapatkan sebuah data yang akurat, transparan dan terlebih lagi dapat dipertanggungjawabkan, merupakan harapan bagi semua institusi. Demikian juga STIMIK Sepuluh Nopember Jayapura yang merupakan institusi perguruan tinggi, yang terus dipantau dari berbagai pihak seperti mahasiswa, orang tua mahsiswa siswa dan pemangku kepentingan di dalam organisasinya. STIMIK Sepuluh Nopember Jayapura, salah satu perguruan tinggi di provinsi papua yang selalu memperoleh kuota beasiswa bidikmisi dari pemerintah setiap tahun, selanjutnya lembaga menyalurkan kepada Mahasiswa yang berhak dan memenuhi persyaratan. Pada penelitian ini memberikan sepuluh orang mahasiswa sebagai contoh yang dapat dilihat pada tabel 1, data tersebut diperoleh dari STIMIK Sepuluh Nopember Jayapura, melalui wawancara dan observasi.

Tabel 1. Daftar Mahasiswa

\begin{tabular}{lcl}
\hline Code & Id Student & \multicolumn{1}{c}{ Name } \\
\hline M-01 & 201915008 & Agustinus Kulwy \\
\hline M-02 & 201915013 & Bernadus Bate \\
\hline M-03 & 201915030 & Bertha Yaruyap \\
\hline M-04 & 201915037 & Ester Numberi \\
\hline M-05 & 201915044 & Omar Paramban \\
\hline M-06 & 201915025 & Moses Fatagur \\
\hline M-07 & 201915027 & Parno Mou \\
\hline M-08 & 201915043 & Ponco Widayanto \\
\hline M-09 & 201915042 & Triyanto \\
\hline M-10 & 201915028 & Yoseph Menekir \\
\hline
\end{tabular}

Tabel 1 memberikan informasi data mahasiswa yang digunakan didalam penelitian ini, data mahasiswa tersebut berasal dari angkatan tahun 2019. Untuk memperoleh beasiswa selain persyaratan ada beberapa kriteria yang dapat di pertimbangkan oleh tim seleksi beasiswa, adapun kriteria yang digunakan dapat dilihat pada Tabel 2.

Tabel 2. Daftar Kriteria

\begin{tabular}{|c|c|c|c|}
\hline Kriteria & Kode & Range & Value \\
\hline \multirow[t]{3}{*}{ Potensi Akademik } & \multirow[t]{3}{*}{ Cr-01 } & $>80$ & 3 \\
\hline & & $>60 \&<=80$ & 2 \\
\hline & & $<=60$ & 1 \\
\hline \multirow{3}{*}{ Pendapatan Orang Tua } & \multirow{3}{*}{ Cr-02 } & $<$ Rp. 1.500 .000 & 3 \\
\hline & & $\begin{array}{c}>\text { Rp. } 1.500 .000 \&<<=\text { Rp. } \\
4.000 .000\end{array}$ & 2 \\
\hline & & >Rp. 4.000 .000 & 1 \\
\hline \multirow[t]{3}{*}{ Jumlah Tanggungan Orang Tua } & \multirow[t]{3}{*}{ Cr-03 } & $<=2$ & 3 \\
\hline & & $>2 \&<=5$ & 2 \\
\hline & & $>5$ & 1 \\
\hline \multirow[t]{3}{*}{ Kelengkapan Berkas } & \multirow[t]{3}{*}{ Cr-04 } & $<=2$ & 3 \\
\hline & & 4 & 2 \\
\hline & & 4 & 1 \\
\hline \multirow[t]{3}{*}{ Alat Transportasi Ke Kampus } & \multirow[t]{3}{*}{ Cr-05 } & Berjalan Kaki & 3 \\
\hline & & Transportsi Umum & 2 \\
\hline & & Milik Sendiri & 1 \\
\hline
\end{tabular}


Citec Journal, Vol. 8, No. 1, Januari 2021

ISSN: 2354-5771

Pada Tabel 2 memperlihatkan lima kriteria yang dimanfaatkan dalam pembuatan sistem pendukung keputusan, untuk memudahkan setiap kiteria diberikan kode, kriteria pertama Potensi akademik diberi kode Cr-01, pendapatan orang tua adalah Cr-02, jumlah tanggungan orang tua diberi kode $\mathrm{Cr}-03$, kelengkapan berkas diberi kode $\mathrm{Cr}-04$ sedangkan transportasi ke kampus adalah Cr-05. Selain code, kriteria juga masing-masing memiliki nilai, sebagai contoh kriteria academic potential akan memperoleh nilai 3 jika nilai rata-rata pengusul $>80$, dan jika $>60 \&$ $<=80$ maka di beri nilai 2 , sedangkan jika $<=60$ maka diberi nilai 1 .

\subsection{Nilai Alternatif} Tabel 3.

Setiap alternatif yang tersedia masing-masing memiliki nilai yang dapat dilihat pada

Tabel 3. Nilai Alternatif

\begin{tabular}{llllll}
\hline Alternatif & Cr-01 & Cr-02 & Cr-03 & Cr-04 & Cr-05 \\
\hline M-01 & 75 & $3,000,000$ & 2 & 3 & Transportasi Umum \\
\hline M-02 & 90 & $7,000,100$ & 4 & 4 & Milik Sendiri \\
\hline M-03 & 89 & $3,700,000$ & 3 & 4 & Transportasi Umum \\
\hline M-04 & 86 & $9,000,000$ & 6 & 4 & Milik Sendiri \\
\hline M-05 & 77 & $2,300,000$ & 5 & 2 & Berjalan kaki \\
\hline M-06 & 81 & $1,250,000$ & 3 & 4 & Berjalan kaki \\
\hline M-07 & 77 & $3,516,000$ & 4 & 4 & Transportasi Umum \\
\hline M-08 & 91 & $1,800,000$ & 3 & 3 & Berjalan kaki \\
\hline M-09 & 86 & $1,900,000$ & 6 & 4 & Berjalan kaki \\
\hline M-10 & 93 & $5,500,000$ & 1 & 4 & Milik Sendiri \\
\hline
\end{tabular}

Tabel 3 menunjukkan nilai pada setiap alternatif yang tersedia, alternatif 1 dengan kode M-01 mimiliki nilai Cr-01=75, Cr-02 Rp.3.000.000, Cr-03=2, Cr-04=4 dan Cr-05 adalah transportasi umum.

\subsection{Jarak Antara Nilai Alternatif dan Nilai Ideal}

Untuk nilai ideal pada setiap kriteria dapat ditentukan oleh pengguna, sebagai contoh untuk Cr-02 memiliki nilai ideal $=3$, Cr- $02=3$, Cr-03=2, Cr-04=3 dan $\mathrm{Cr}-05=3$. Tabel kebutuhan pengguna dapat dilihat pada tabel 4 .

Tabel 4. Kebutuhan Pengguna

\begin{tabular}{lll}
\hline Kriteria & Kebutuhan & Nilai \\
\hline $\mathrm{Cr}-01$ & $>80$ & 3 \\
\hline $\mathrm{Cr}-02$ & $>$ Rp $1.500 .000 \&<=$ Rp. 4.000 .000 & 2 \\
\hline $\mathrm{Cr}-03$ & $>2 \&<=5$ & 2 \\
\hline $\mathrm{Cr}-04$ & 4 & 3 \\
\hline $\mathrm{Cr}-05$ & Public transportation & 2 \\
\hline
\end{tabular}

Tabel 4 menjelaskan tetang nilai ideal dari kebutuhan pengguna pada masing-masing kriteria, pada Cr-01 di targetkan pada nilai 3, Cr-02 pada nilai 2, Cr-03 pada nilai 3, Cr-04 pada nilai 4 dan pada Cr-05 di targetkan pada nilai 2.

\subsection{Nilai Gap}

Untuk memperoleh nilai gap dalam metode profile matching dapat menggunakan persamaan gap=profile atribut - profile target, dan hasil dari persamaan tersebut dapat dilihat pada Tabel 5. 
Tabel 5. Nilai Gap

\begin{tabular}{lccccc}
\hline Alternative & Cr-01 & Cr-02 & Cr-03 & Cr-04 & Cr-05 \\
\hline M-01 & -1 & 0 & -1 & -1 & 0 \\
\hline M-02 & 0 & -1 & 0 & 0 & -1 \\
\hline M-03 & 0 & 0 & 0 & 0 & 0 \\
\hline M-04 & 0 & -1 & 1 & 0 & -1 \\
\hline M-05 & 0 & 0 & 0 & -2 & 1 \\
\hline M-06 & 0 & 1 & 0 & 0 & 1 \\
\hline M-07 & -1 & 0 & 0 & 0 & 0 \\
\hline M-08 & 0 & 0 & 0 & -1 & 1 \\
\hline M-09 & 0 & 0 & 0 & 0 & 1 \\
\hline M-10 & 0 & -1 & -1 & 0 & -1 \\
\hline
\end{tabular}

Pada Tabel 5 merupakan hasil pengurangan antara profil atribut dan profil target, selanjutnya nilai-nilai tersebut akan diubah menjadi nilai baru, dengan aturan jika selisih $=0$ maka nilai baru akan di peroleh $=3$ karena nilai tertinggi adalah 3 , dan jika selisih nilai 1 maka nilai baru $=2,5$, jika -1 maka nilainya $=2$, jika selisihnya 2 maka nilai barunya $=1,5$ dan jika -2 maka nilai barunya $=1$.

\subsection{Nilai Baru}

Nilai pada Tabel 5 yang dikonversikan mengikuti aturan menjadi nilai baru, hasilnya dapat dilihat pada tabel 6 .

Tabel 6. Nilai Baru

\begin{tabular}{lccccc}
\hline Alternatif & Cr-01 & Cr-02 & Cr-03 & Cr-04 & Cr-05 \\
\hline M-01 & 2 & 3 & 2 & 2 & 3 \\
\hline M-02 & 3 & 2 & 3 & 3 & 2 \\
\hline M-03 & 3 & 3 & 3 & 3 & 3 \\
\hline M-04 & 3 & 2 & 2,5 & 3 & 2 \\
\hline M-05 & 3 & 3 & 3 & 1 & 2,5 \\
\hline M-06 & 3 & 2,5 & 3 & 3 & 2,5 \\
\hline M-07 & 2 & 3 & 3 & 3 & 3 \\
\hline M-08 & 3 & 3 & 3 & 2 & 2,5 \\
\hline M-09 & 3 & 3 & 3 & 3 & 2,5 \\
\hline M-10 & 3 & 2 & 2 & 3 & 2 \\
\hline
\end{tabular}

Pada Tabel 6 merupakan hasil konversi dari nilai gap menjadi nilai baru, yang selanjutnya di gunakan untuk menghitung nilai core factor dan secondary factor. Salah satu contoh nilai alternatif M-05 memiliki nilai baru pada masing-masing kriteria $\mathrm{Cr}-91=3, \mathrm{Cr}-02=3, \mathrm{Cr}-03=3$, Cr$04=1$ dan $\mathrm{Cr}-05=2,5$.

\subsection{Core Factor (CF) dan Secondary Factor (SF)}

Terdapat dua jenis kriteria yaitu core factor (cf) yang merupakan kriteria yang paling utama, sedangkan secondary factor (sf) yang merupakan kriteria tambahan. Pada tabel 7 menujukkan nilai cf dan sf. 
Citec Journal, Vol. 8, No. 1, Januari 2021

Tabel 7. Nilai Core Factor dan Secondary Factor

\begin{tabular}{lccllll}
\hline \multicolumn{1}{c}{ Alternatif } & CF & SF & CF Value & SF Value & CF+SF & Rangking \\
\hline M-01 & 2,33 & 2,50 & 1,52 & 0,88 & 2,39 & 10 \\
\hline M-02 & 2,67 & 2,50 & 1,73 & 0,88 & 2,61 & 6 \\
\hline M-03 & 3,00 & 3,00 & 1,95 & 1,05 & 3,00 & 1 \\
\hline M-04 & 2,67 & 2,25 & 1,73 & 0,79 & 2,52 & 7 \\
\hline M-05 & 2,33 & 2,75 & 1,52 & 0,96 & 2,48 & 8 \\
\hline M-06 & 2,83 & 2,75 & 1,84 & 0,96 & 2,80 & 3 \\
\hline M-07 & 2,67 & 3,00 & 1,73 & 1,05 & 2,78 & 4 \\
\hline M-08 & 2,67 & 2,75 & 1,73 & 0,96 & 2,70 & 5 \\
\hline M-10 & 3,00 & 2,75 & 1,95 & 0,96 & 2,91 & 2 \\
\hline
\end{tabular}

Jadi, pada Tabel 7 menunjukan sebuah wisdom jika memilih potensi akademik, pendapatan orang tua, kelengkapan berkas, menjadi core factor (CF) sedangkan kriteria jumlah tanggungan dan transportasi ke kampus dijadikan sebagai kriteria tambahan. Core factor diberikan nilai prioritas sebesar 65\% sedangkan secondary factor diberikan nilai sebesar 35\%.

\subsection{Analisis Hasil Penelitian}

Berdasarkan nilai pada Tabel 7, STIMIK Sepuluh Nopember Jayapura akan meloloskan berkas sebanyak lima dan diurutkan mulai dari rank 1-5 yaitu M-03, M-09, M-06, M-07, dan M08. Dengan memanfaatkan metode profile matching dalam merancang sistem pendukung keputusan memiliki keunggulan dengan adanya core factor dan secondary factor sehingga pengguna dapat menentukan secara mandiri mana yang termasuk kriteria utama dan mana yang termasuk kriteria tambahan, Selain itu metode profile matching sangat cocok diterapkan pada perhitungan dari aspek ekonomi dengan mencari nilai GAP yang merupakan angka relatif pada sisi ekonomi, hal tersebut tidak dapat diterapkan pada metode seperti SAW.

\subsection{Pengujian}

Pengujian bertujuan untuk mengetahui tingkat kesalahan yang terjadi pada sistem, selain itu dapat memberikan akurasi dan kenyamanan pengguna sistem.

\subsection{1. $\quad$ User Acceptence Test (UAT)}

Metode pengujian ini bertujuan mengetahui apakah sistem pendukung keputusan dapat menyelesaikan kasus yang sedang terjadi. Adapun hasil pengujian dapat dilihat pada Gambar 4.

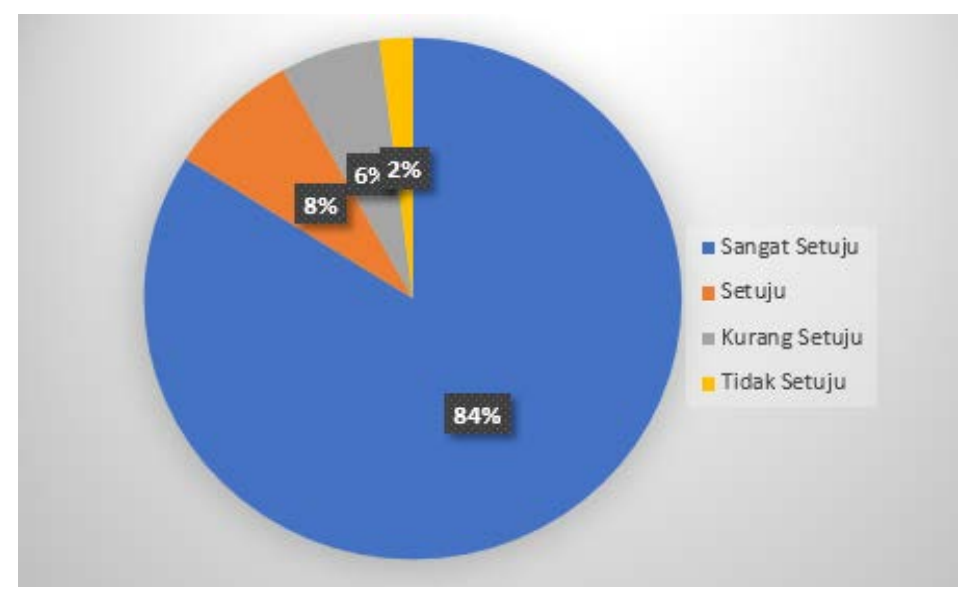

Gambar 4. Hasil Pengujian 
Pada pengujian yang dilakukan memberikan kuesioner pada pengguna sebanyak 5 orang dan setiap kuesioner berisi lima pertanyaan dengan jawaban sangat setuju, setuju, kurang setuju, dan tidak setuju. Hasil yang diperoleh cukup memuaskan karena sebanyak $84 \%$ menjawab positif yaitu sangat setuju, $8 \%$ responden menjawab setuju, $6 \%$ kurang setuju dan sisanya sebanyak $2 \%$ menjawab tidak setuju.

\section{KESIMPULAN}

Berdasarkan hasil penelitian yang dimulai dari pengumpulan data, pemrosesan data, design prototype dan testing maka dapat ditarik beberapa kesimpulan:

1. Pencocokan antara hasil dari prototype dan perhitungan manual memperoleh hasil yang sama.

2. Hasil testing sebanyak $84 \%$ menjawab positif terhadap manfaat sistem dan metode profile matching.

3. Wisdom yang diperoleh dalam bentuk ranking sesuai dengan kondisi pada STIMIK Sepuluh Nopember Jayapura.

\section{SARAN}

Sebaiknya Penerapan metode profile matching dapat dikombinasikan dengan metode yang lain untuk memperoleh hasil yang maksimal.

\section{DAFTAR PUSTAKA}

[1] Hijriana, N., Karyadiputra, E., 2018, SSistem Pendukung Keputusan Seleksi Beasiswa Tingkat Universitas Menggunakan Metode Topsis, Jurnal Al Ulum Sains dan Teknologi, No. 2, Vol. 3, Hal. 90-96

[2] Hasan, P., Utami, E., Yunita, S., Pawan, E., Kaharuddin., 2019, Selection of Scholarship Acceptance Using AHP and TOPSIS Methods, 2019 International Conference on Information and Communications Technology (ICOIACT), Yogyakarta, 24-25 Juli

[3] Siswanto, A., 2017, The Implementation of 12 Years Compulsory Education Pioneering Program Senior High School in Bantul Regency, Jurnal, Hanata Widya, No. 7, Vol 6, Hal. Pages 55-65

[4] Utary, D., Agusdin., Hermanto., 2018, Analisis Kebutuhan Pengembangan SDM Bidang Bina Marga Dinas PUPR Provinsi NTB, Jurnal Magister Manajemen Universitas Mataram, No. 2, Vol. 7, Hal. 36-49

[5] Susilowati, T., Anggraeni, E. Y., Fauzi., Andewi, W., Handayani, Y., Maseleno, A., 2018, Using Profile Matching Method to Employee Position Movement, International Journal of Pure and Applied Mathematics, No. 7, Vol. 118, Hal. 415 - 423

[6] Pawan, E., Jasuma, A., Arif, A. Y., Kusrini, 2020, Sistem Pendukung Keputusan Menentukan Bibit Padi Terbaik Menggunakan Metode Gap Kompetensi Decision Support Systems Determine the Best Rice Seeds Using the Competence Gap Method, Jurnal Sisfotenika, No. 1, Vol. 10, Hal. 24-36.

[7] Andrianto, C. B., Kusrini., Al Fatta, H., 2017, Analisis Sistem Pendukung Keputusan Penerima Beasiswa Di Smp Muhammadiyah 2 Kalasan, Jurnal Teknologi Informasi, No. 34, Vol. 12, Hal. 46-60.

[8] Mangapul, G., Adhi, B. P., 2017, Sistem Pendukung Keputusan Untuk Menentukan Penerima Beasiswa Di Fakultas Teknik Univeristas Negeri Jakarta Dengan Model Fuzzy Multiple 
Attribute Menggunakan Metode SAW, Jurnal Pendidikan Teknik Informatika dan Komputer, No. 2, Vol. 1, Hal. 126-133

[9] Setiyowati, A., Ramadhani, L. A., Amin, M. K., 2019, Sistem Pendukung Keputusan Menentukan Penerima Beasiswa Kurang Mampu Menggunakan Metode Profile Matching, Jurnal Informatika Upgris, No. 1, Vol. 5, Hal. 1-5

[10] Qorik, M. F. N., Slamin., Pandunata., 2019, Sistem Pendukung Keputusan Seleksi Beasiswa Situbondo Unggul Menggunakan Metode Simple Additive Weighting dan Profile Matching, INFORMAL Informatics Jurnal, No. 1, Vol. 3.

[11] Nisa, K., Sutinah, E., 2018, Profile Matching for Server and Network Maintenance Vendor Selection Decision Support Systems, Jurnal Informatika, No. 2, Vol. 5, Hal. 262-269

[12] Kusrini, 2007, Concept and Application of Decision Support Systems, Andi Offset, Yogyakarta.

[13] Puspitasari, D. I., Kholdani, A. F. R., 2017, Penerapan Sistem Pendukung Keputusan Dengan Analisis Gap Untuk Pemilihan Mahasiswa Berprestasi Tingkat Fakultas (Pada Fakultas Teknologi Informasi Uniska), Technologia Jurnal Ilmiah, No. 1, Vol. 8

[14] Tobing, D. M. L., Pawan, E., Neno, F. E., Kusrini., 2019, Expert System to Detect Disease Rice Plants Using Forward Chaining, SISFOTENIKA, No. 2, Vol. 9, Hal. 10-48

[15] David, 2014, Penerapan Forward Chaining Dalam Sistem Pakar Diagnosa Hama Dan Penyakit Tanaman Jagung, Seminar Nasional Inforatika SNIf 2014, Medan, 12-14 September

[16] Dewi, W. S., Hammad, R., Pawan, E., Yuliana., 2018, Analisis dan Perancangan Sistem Basis Data SIAP PPDB Online, Seminar Nasional Sistem Informasi dan Teknologi Informasi 2018, Pontianak, 12 Juli

[17] Pawan, E., Hasan, P., Thamrin, R. M., 2020, Utilization SAW Method to Choose Goods Suppliers at PT. King Computer, CCIT Jurnal, No. 1, Vol. 13, Hal. 111-124

[18] Risa., Yakub., 2014, Perancangan Sistem Informasi Penggajian Pada PT. Eagle Indo Pharma, Jurnal Sisfokom (Sistem Informasi dan Komputer), No. 2, Vol. 3, Hal. 24-29,

[19] Mulyati, S., Sujatmoko, B. A., Wira, T. I. M., Afif, R., Pranata, R. A., 2013, Normalisasi Database Dan Migrasi Database Untuk Memudahkan Manajeman data, Sebatik, No. 2, Vol. 22, Hal. 124-129 